\title{
Involvement of Women in Handloom Segment: An Empirical Study With Reference To Krishna District, Andhra Pradesh
}

\author{
D.Srinivasa Rao ${ }^{1}$, N.Sreedhar ${ }^{2} \&$ B. Ravi Kumar ${ }^{3}$ \\ ${ }^{1}$ Research Scholar - Dept. of Economics, Rayalaseema University, Kurnool,India. \\ ${ }^{2}$ Dept. of Economics, Rayalaseema University, Kurnool, AP. India \\ ${ }^{3}$ Dept. of MBA, Amrita Sai Institute of Science and Technology,India. \\ Correspondence: B. Ravi Kumar, Dept. of MBA, Amrita Sai Institute of Science and Technology,India. \\ To cite this article: Rao, D., Sreedhar, N., \& Kumar, B. R. (2018). Involvement of Women in Handloom Segment: \\ An Empirical Study With Reference To Krishna District, Andhra Pradesh. American Economic \& Social Review, \\ 3(1), 1-11. Retrieved from http://www.cribfb.com/journal/index.php/aesr/article/view/137
}

Received: June 19, 2018

Accepted: June 30, 2018

Online Published: August 25, 2018

\begin{abstract}
The handloom is a traditional craft work of India and it provides employment opportunities to lakhs of people in the rural and urban areas of our country. In the world women constitutes approximately $50 \%$ of the total population but society is still male dominated one. In India women contributed substantially to the economic growth of the country.The relationship between gender and the economy has considerable importance in Indian society. In general attitude of the people women are second grade citizens and they are makers of food, pickles, papads, masalas etc,. But their role is very important in every economic activity, either it is household work or cultivation or industry or service sector etc,. Like the other sectors the role of women weavers is very much important in handloom sector. Handloom sector is unique in India. The handloom weaving is household profession, followed by generations. In these households, women play an important role. Handloom sector is the only manufacturing sector in which women producing for women.
\end{abstract}

Keywords: Women Weavers, Participation of Work, Handloom Sector, Krishna District, Andhra Pradesh

\section{Introduction}

Handloom sector in India is growing and has been undergoing many changes within its structure that affect its main features. Handloom weaving plays an important role in the growth process of the state as well as the country. This sector has been considered prominent because of the traditional artisan craft skills of the weavers which meet the local needs and demands.Irrespective of gender the Handloom sector has self sustaining mechanism.There is a sufficient flexibility for all types of communities to take up handloom production as a profession. In modern times the handloom sector has different strengths. It is simple, and is associated with appropriate technology. Women as a whole in the world wide suffer from secondary status .In India also they are in lower most hierarchy.The discrimination of women is related to her socio-economic status but differs from region to region, in rural and urban areas. 
The Handloom Sector is one of the largest unorganized economic activities after agriculture and constitutes an integral part of the rural and semi rural livelihood. Handloom weaving constitutes one of the richest and most vibrant aspects of the Indian cultural heritage. The sector has an advantage of being less capital intensive, minimal use of power, eco-friendly, and flexibility of small production, openness to innovations and adaptability to market requirements. It is a natural productive asset and tradition at cottage level, which has sustained and grown by transfer of skill from one generation to other.

Handloom weaving is largely decentralized and the weavers are mainly from the vulnerable and weaker sections of the society, who weave for their household needs and also contribute to the production in the textile sector. The weavers of this industry are keeping alive the traditional craft of different States.

The level of artistry and intricacy achieved in the handloom fabrics is unparalleled and certain weaves/designs are still beyond the scope of modern machines. Handloom sector can meet every need ranging from the exquisite fabrics, which takes months to weave, to popular items of mass production for daily use.

As per 3rd Handlooms Census, carried out in 2009-10, more than 43 lakh people are engaged in weaving and allied activities which were 65.5 lakh as per 2nd handloom census conducted during 1995-96. Out of the 38.47 lakh adult weavers and allied workers in the country, $77 \%$ are women and $23 \%$ male weavers, $10 \%$ of the weavers are from scheduled castes (SCs), $18 \%$ of the weavers are from scheduled tribes (STs), $45 \%$ are from other backward classes (OBCs) and $27 \%$ are from other castes.

Objectives of the study

The main purpose of the study is to examine the work participation of women handloom weavers in Krishna district. The objectives of the study are

1) To study the work participation of the women in handloom sector in Krishna district.

2) To study the socio-economic conditions of women handloom weavers in Krishna district.

3) To estimate the improvement in the socio-economic status of women handloom weavers by using government schemes.

4) To study the problems and prospects of handloom industry in Krishna district.

Period of the Study

The study mainly examines the work participation of women weavers in handloom sector in Krishna district from 2006 to 2016 i.e. 10 years period.

Collection of Data

The study is based on primary data and secondary data. We have collected primary data from 70 respondents by using a structured questionnaire and through personal interview method. The secondary data was collected from books, periodic journals, articles related to the present research.

\section{Primary Data}

The main source of the data is from the handloom weavers who are working under societies or independent weavers. For primary data collection 70 women weavers were selected. A structured questionnaire is used for the survey which contain simple, multiple choice questions. For primary data collection the observation method, personal interview method and group discussion method are used.

Secondary Data

Secondary data has been collected from published and unpublished reports by the government, departments and societies of the handloom sector and also from books, periodic journals and various websites related to present research study and handloom census of Ministry of Textiles ,Government of India.

Sampling Techniques

Simple random sampling was used in present research. Women handloom weavers is the sample and Krishna district is the population.

Area of the Study

This study was limited to women handloom weavers of seven mandals in Krishna district. The weavers spread throughout the district. Majority of weavers reside in Guduru, Pedana ,Ghantasala , Bandar ,Challapalli ,Movva and Gannavaram mandals.

Sample Size. There are 58 primary handloom weavers co-operative societies existed in Krishna district with membership of 7,047 weaver artisans and 4,865 weavers are outside the co-operative fold. That is 11,912 handloom weavers in Krishna District. Among them 7,085 weavers are women weavers. A sample of 70 weavers are randomly selected from Krishna district, Andhra Pradesh.

Analysis and Interpretation of Data

The data is collected from 70 sample respondents. A structured questionnaire was given to the respondents to collect primary data. The data is analyzed by using the tables on the basis of age, sex, marital status, literacy, size of the family, working hours, income per month and health ground. 
Table - 1 Age wise Classification of women weavers

\begin{tabular}{cccc}
\hline Sl. No & Age group & No. of respondents & percentage \\
\hline 1 & Up to 20 yrs & 08 & 11.43 \\
\hline 2 & $20-40$ yrs & 35 & 50.00 \\
\hline 3 & $40-60$ yrs & 21 & 30.00 \\
\hline 4 & Above 60 years & 06 & 08.57 \\
\hline
\end{tabular}

\section{Source: primary data}

According to the above table majority of women weaver respondents $(50.0 \%)$ belong to the age group between 20 and 40 years. Only 6 members are above the age of 60 years with $8.57 \%$

\section{AGE GROUP (YEARS)}

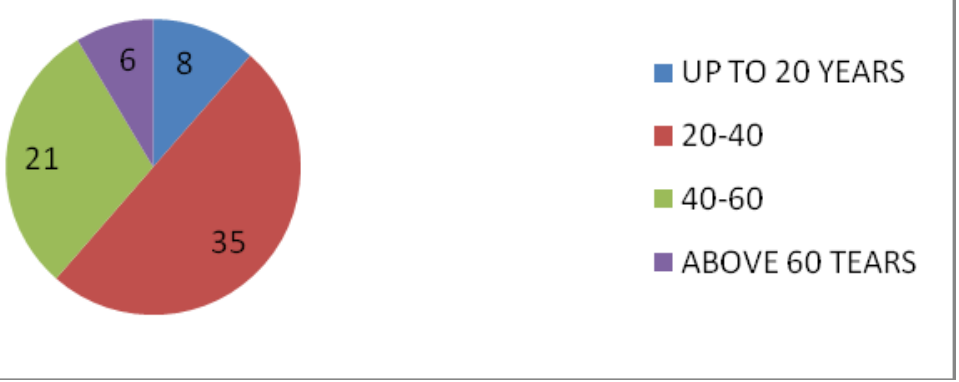

Table - 2 Type of work

\begin{tabular}{llll}
\hline Sl. No & Nature of work & No. of respondents & Percentage \\
\hline 1 & weaving & 14 & 20.00 \\
\hline 2 & Bobbin winding & 18 & 25.71 \\
\hline 3 & Warping & 17 & 24.29 \\
\hline 4 & Dyeing & 16 & 22.86 \\
\hline 5 & Others & 05 & 07.14 \\
\hline & Total & 70 & 100 \\
\hline
\end{tabular}

Source: primary data

According to the data the participation of women weaver respondents is same in all work areas but less in weaving area.

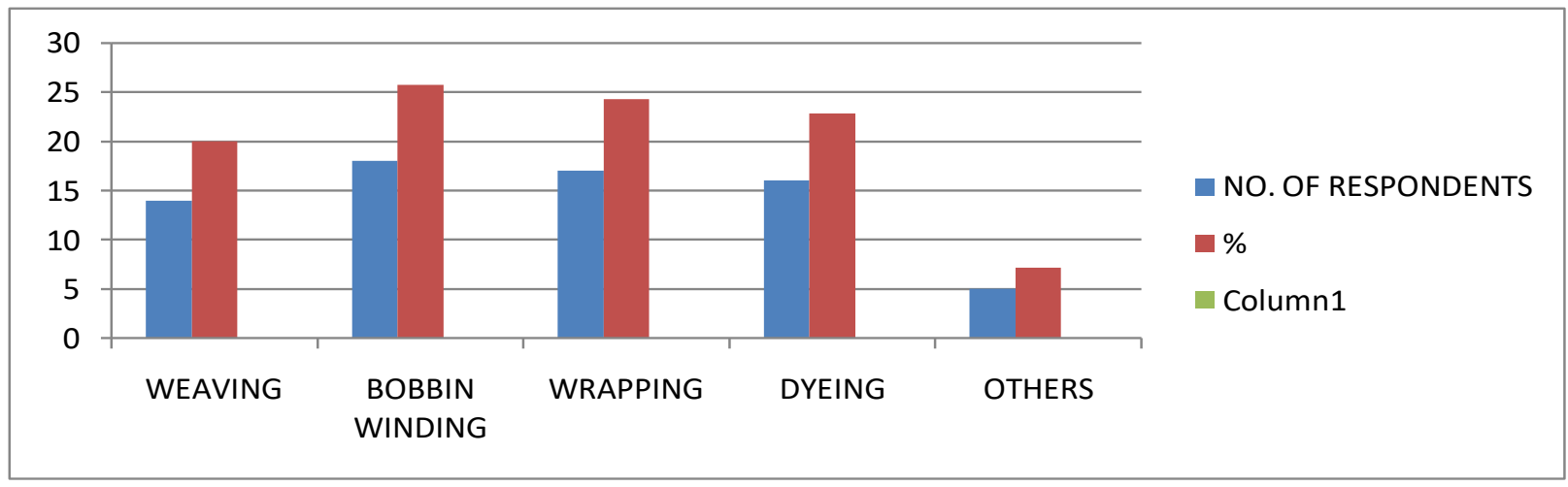


Table -3 Community wise Classification of women weavers

\begin{tabular}{llll}
\hline Sl. No & Community & No. of respondents & percentage \\
\hline 1 & BC & 55 & 78.57 \\
\hline 2 & SC & 07 & 10 \\
\hline 3 & ST & 00 & 00 \\
\hline 4 & Others & 08 & 11.43 \\
\hline & Total & 70 & 100 \\
\hline
\end{tabular}

\section{community distribution}

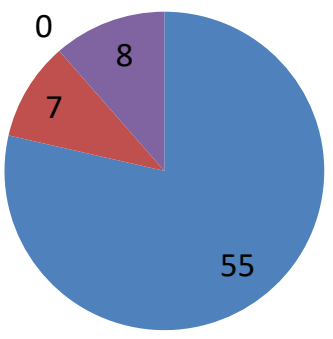

backward caste

schedule caste

scheduled tribe

athers

According to the data 55 weaver respondents out of 70 belong to backward community with $78.57 \%, 11.43 \%$ are belong to other communities, $10 \%$ respondents belong to scheduled caste and none of the respondents are belong to scheduled tribe.

\begin{tabular}{llll} 
Table -4 & Religion wise Classification of women weavers & \\
\hline Sl. No & Religion & No. of respondents & percentage \\
\hline 1 & Hindu & 57 & 81.43 \\
\hline 2 & Muslim & 07 & 10.0 \\
\hline 3 & Christian & 06 & 8.57 \\
\hline 4 & Others & 00 & 00 \\
\hline & Total & 70 & 100 \\
\hline
\end{tabular}

Source: primary data

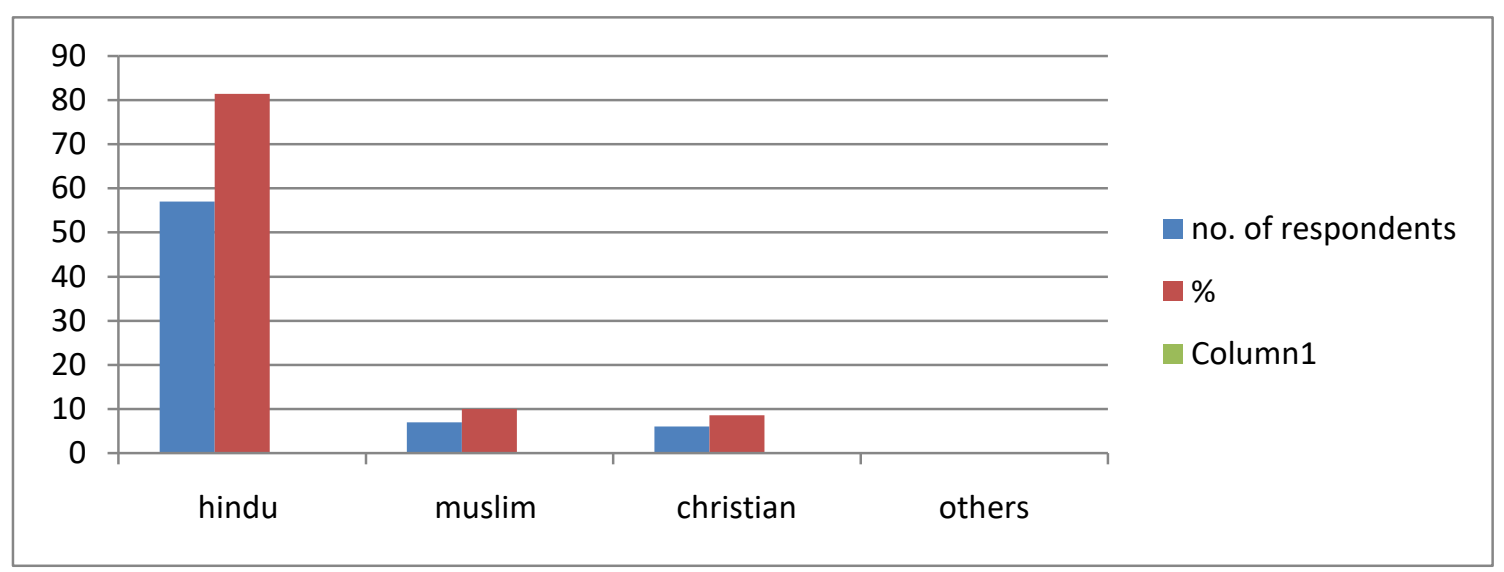


According to the study majority of the women respondents (81.43\%) belong to Hindu religion, $10 \%$ respondents belong to Muslim and the rest belong to Christian religion.

Table -5 Classifications of women weavers on the basis of marital status

\begin{tabular}{llll}
\hline Sl. No & Marital status & No. of respondents & percentage \\
\hline 1 & Married & 61 & 87.14 \\
\hline 2 & Un married & 01 & 01.43 \\
\hline 3 & Widow & 07 & 10.0 \\
\hline 4 & Divorcee & 01 & 01.43 \\
\hline & Total & 70 & 100
\end{tabular}

Source: primary data

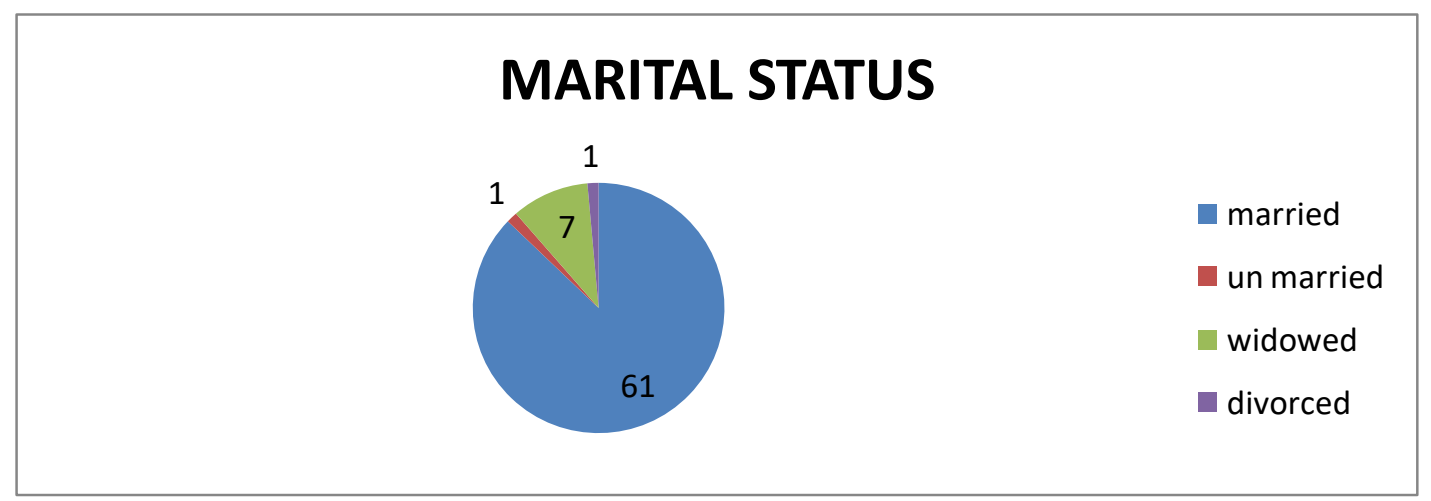

According to the data majority of the women respondents 61 out of $70(87.14 \%)$ are married and $10 \%$ are widowed. Unmarried and divorced are $1 \%$ of total respondents.

Table -6 Classification of women weavers on literacy level

\begin{tabular}{llll}
\hline Sl. no & Literacy level & No. of respondents & Percentage \\
\hline 1 & Illiterates & 21 & 30.00 \\
\hline 2 & $1-5$ class & 18 & 25.71 \\
\hline 3 & $6-10$ class & 24 & 34.29 \\
\hline 4 & $10+2$ class & 07 & 10.00 \\
\hline 5 & Graduation & 00 & 00 \\
\hline & Total & 70 & 100 \\
\hline
\end{tabular}

Source: primary data

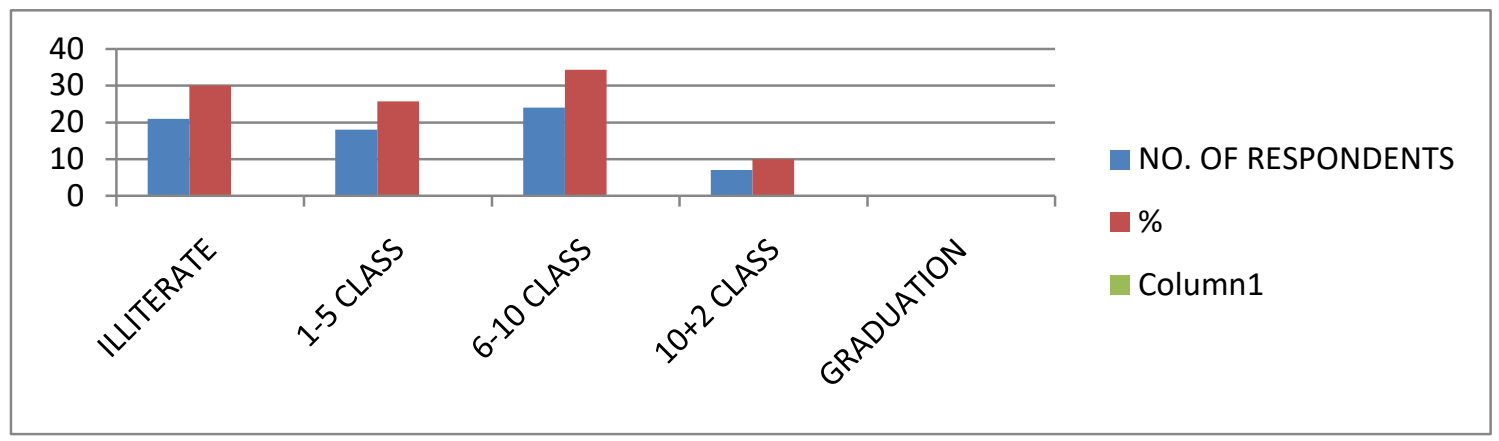

According to the data $30 \%$ of women respondents are illiterates. $25.71 \%$ completed their primary education and $34.29 \%$ completed secondary education. Only $10 \%$ are studied up to inter level and none of them are at graduation level. 
Table -7 Type of family

\begin{tabular}{llll}
\hline Sl. No & Type of family & No. of respondents & Percentage \\
\hline 1 & Nuclear & 45 & 64.29 \\
\hline 2 & Joint & 25 & 35.71 \\
\hline & Total & 70 & 100 \\
\hline
\end{tabular}

Source: primary data

According to the data majority of the respondents (64.29\%) are under nuclear families and $35.71 \%$ are under joint families.

\section{TYPE OF FAMILY}

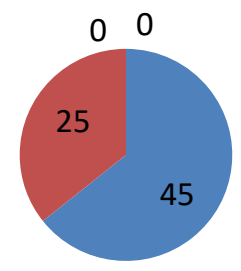

NUCLEAR FAMILY

JOINT FAMILY

Table $-8 \quad$ Size of family

\begin{tabular}{llll}
\hline Sl. no & Size of family & No. of respondents & Percentage \\
\hline 1 & Small (up to 3) & 15 & 21.43 \\
\hline 2 & Medium(4-6) & 35 & 50.00 \\
\hline 3 & Large(above 6) & 20 & 28.57 \\
\hline & Total & 70 & 100 \\
\hline
\end{tabular}

Source: primary data

According to the data $50 \%$ of the women weaver respondents have medium size of family which consists of 4 to 6 members. Very less $(21.43 \%)$ number of respondents consisting up to 3 members which is very small family.

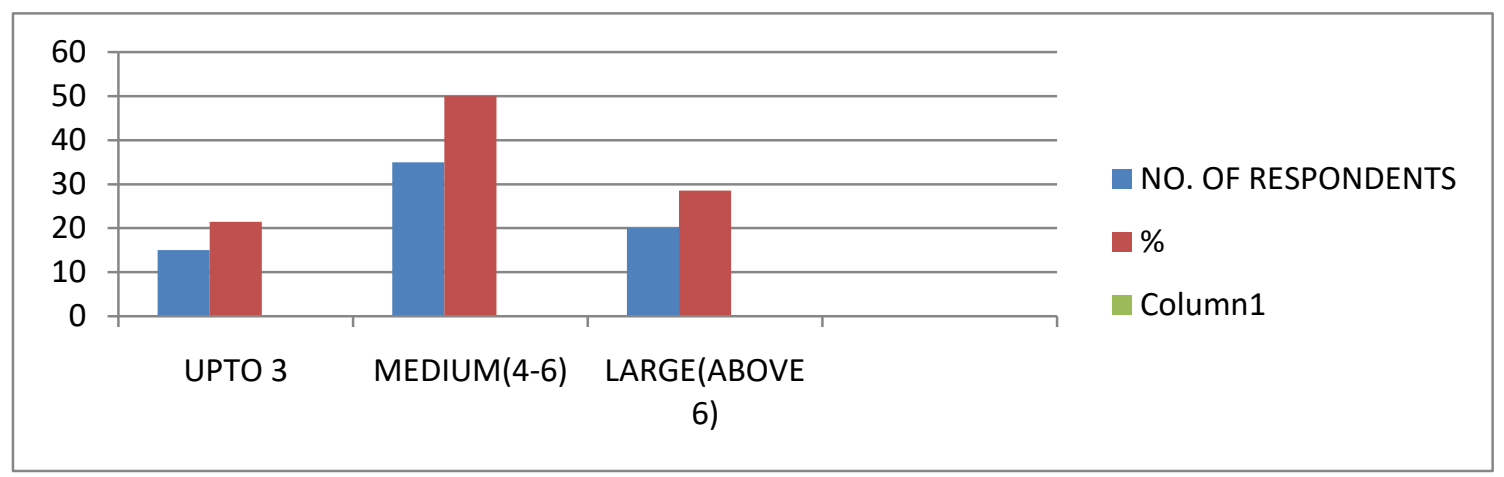

Table-9.Residential status

\begin{tabular}{llll}
\hline Sl.No & House & No. of respondents & Percentage \\
\hline 1 & Own & 60 & 85.71 \\
\hline 2 & Rent & 10 & 14.29 \\
\hline & Total & 70 & 100 \\
\hline
\end{tabular}

Source: primary data 
According to the data majority of the respondents $(85.71 \%$ ) have own houses and $14.29 \%$ of the respondents are living in rented houses.

\section{RESIDENTIAL STATUS}

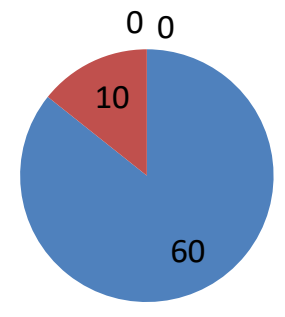

Table-10. Type of house

\begin{tabular}{llll}
\hline Sl.no & Type of house & No. of respondents & percentage \\
\hline 1 & Thatched & 39 & 55.71 \\
\hline 2 & Tiled & 14 & 20.0 \\
\hline 3 & R.C.C & 07 & 10.00 \\
\hline 4 & Sheds & 10 & 14.29 \\
\hline & Total & 70 & 100 \\
\hline
\end{tabular}

Source: primary data

According to the data majority of the respondents $(55.71 \%)$ are dwelling in thatched houses. A few respondents $(10.0 \%)$ are dwelling in R.C.C houses.

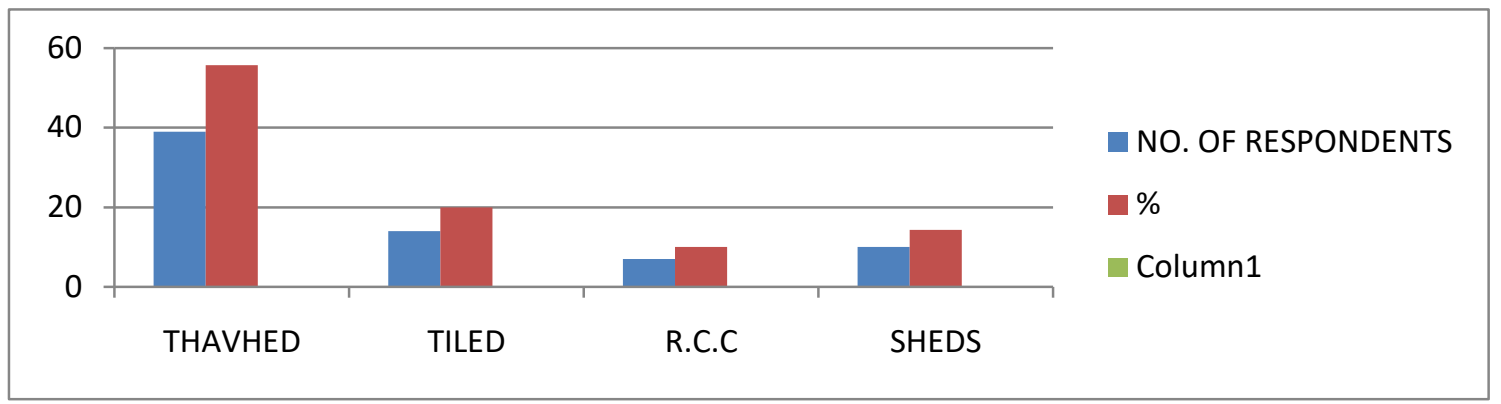

Table-11.Selection of job

\begin{tabular}{llll}
\hline Sl. no & Preference & No. of respondents & Percentage \\
\hline 1 & Inheritance & 52 & 74.29 \\
\hline 2 & Job opportunities & 10 & 14.28 \\
\hline 3 & Interest & 08 & 11.43 \\
\hline & Total & 70 & 100 \\
\hline & & Source: primary data
\end{tabular}

According to the data majority of the women weaver respondents $(74.29 \%)$ are choosing the occupation by inheritance. Only $11.43 \%$ of the respondents prefer the occupation by their interest. 


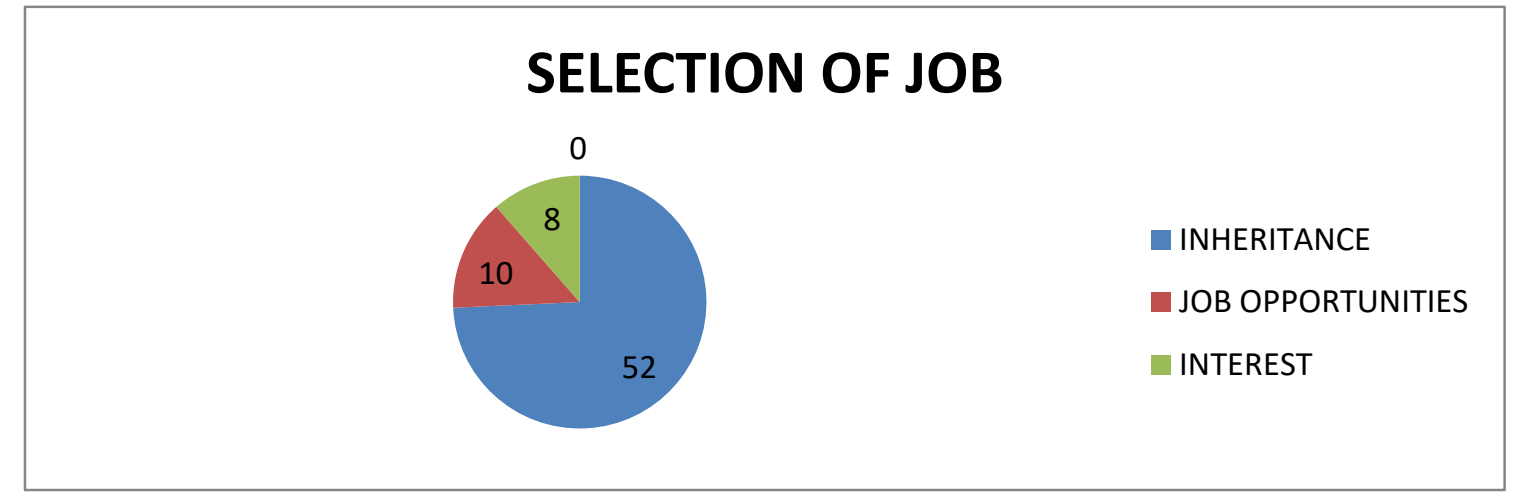

Table-12.Category of weavers

\begin{tabular}{llll}
\hline Sl. no & Category & No. of respondents & Percentage \\
\hline 1 & Independent weavers & 04 & 5.71 \\
\hline 2 & Working under master weaver & 28 & 40.0 \\
\hline 3 & $\begin{array}{l}\text { Working under Co-operative } \\
\text { weavers }\end{array}$ & 38 & 54.29 \\
\hline & Total & 70 & 100 \\
\hline
\end{tabular}

Source: primary data

According to the data majority of the respondents $(54.29 \%)$ are working under co-operative societies. $40 \%$ of the respondents are working under master weavers. Only $5.71 \%$ of the respondents are independent weavers.

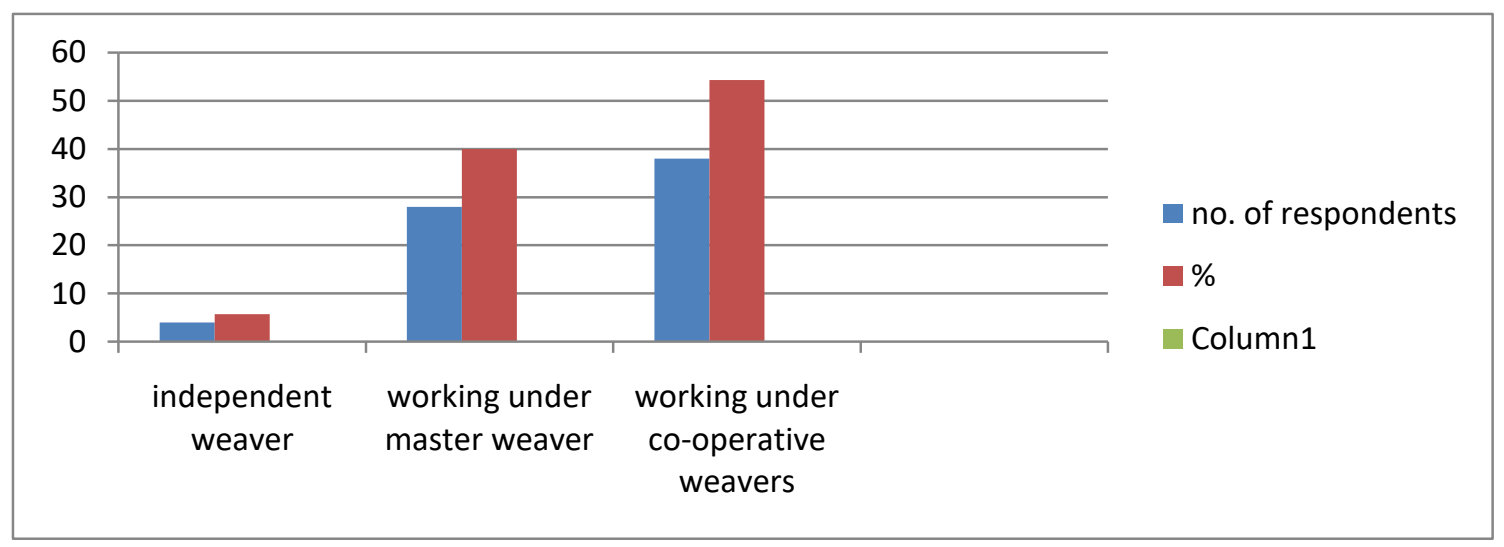

Table-13. Working hours per day

\begin{tabular}{llll}
\hline Sl. no & Working hours & No. of respondents & Percentage \\
\hline 1 & Up to $8 \mathrm{hrs}$ & 63 & 90.00 \\
\hline 2 & $8-12 \mathrm{hrs}$ & 07 & 10.00 \\
\hline 3 & Above $12 \mathrm{hrs}$ & 00 & 00 \\
\hline & Total & 70 & 100 \\
\hline
\end{tabular}

Source: primary data

According to the data majority of the respondents (90\%) are working up to 8 hours per day and only $10 \%$ of the weavers are working 8-12 hours per day. 


\section{working hours per day}

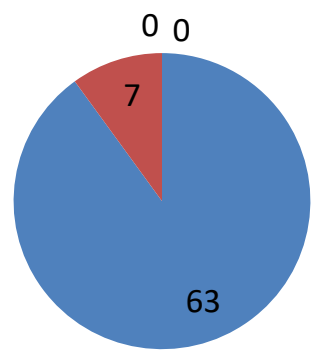

up to 8 hours

8-12 hours

above 12 hours

Table-14. Wage levels

\begin{tabular}{llll}
\hline Sl. no & Average income per day & No. of respondents & Percentage \\
\hline 1 & Rs. $100-200$ & 40 & 57.14 \\
\hline 2 & Rs. 201 -300 & 26 & 37.15 \\
\hline 3 & Above Rs. 300 & 04 & 05.71 \\
\hline & Total & 70 & 100 \\
\hline
\end{tabular}

Source: primary data

According to the data majority of the respondents (57.14\%) are earning in between Rs. 100 to 200 per day. Only $5.71 \%$ of the respondents income is Rs.300 above.

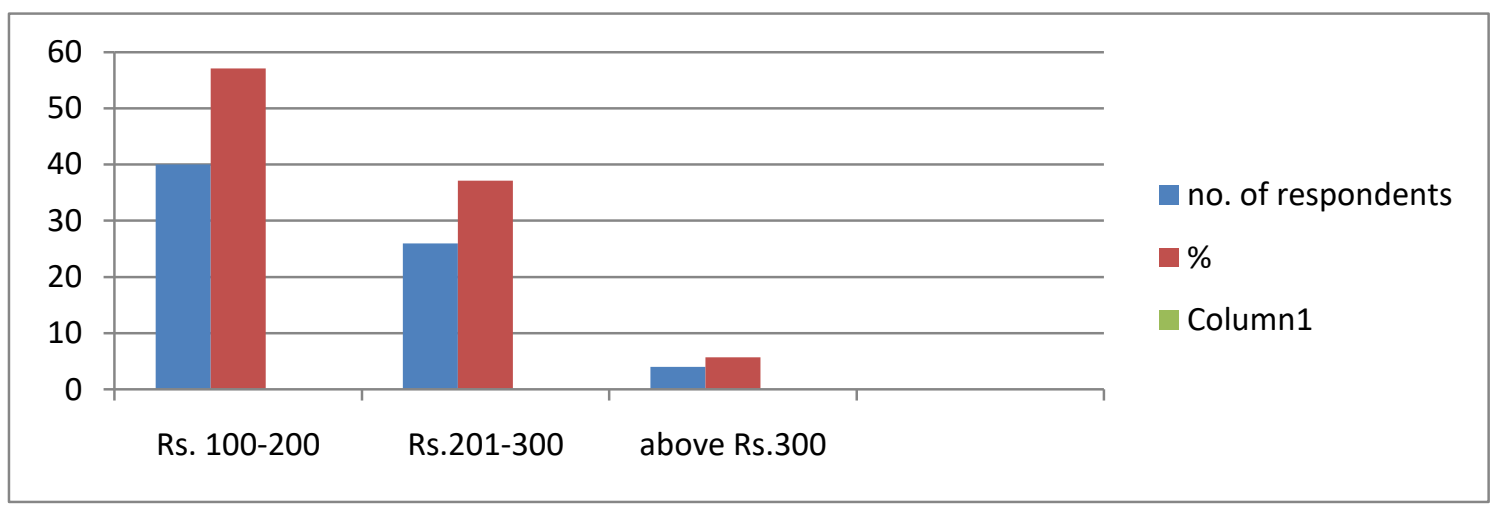

Table -15 Health problems

\begin{tabular}{llll}
\hline Sl.no & Health problems & No. of respondents & percentage \\
\hline 1 & Eye sight / cataract & 23 & 32.86 \\
\hline 2 & Back pain & 30 & 42.86 \\
\hline 3 & Knee pain / joint pain & 13 & 18.57 \\
\hline 4 & Problem of lungs & 04 & 05.71 \\
\hline & Total & 70 & 100 \\
\hline
\end{tabular}

Source: primary data

According to the data majority of the respondents (42.86\%) are suffering form backpain followed by $32.86 \%$ respondents suffering from eye sight /cataract.

$18.57 \%$ of the respondents are suffering from joint pains and knee pains and only $5.71 \%$ of the respondents suffering from the problem of lungs. 


\section{HEALTH PROBLEMS}

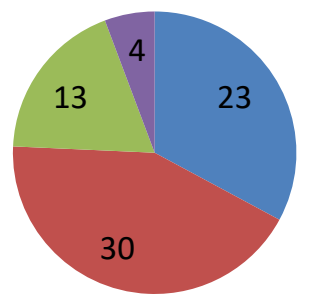

eye sight/cataract

back pain

knee pain/joint pain

problem of lungs

Findings

According to the information collected from the respondents there are some major findings. They are:

1.Majority of women weaver respondents $(50.0 \%)$ belong to the age group between 20 and 40 years

2. The participation of women weaver respondents is same in all work areas but less in weaving area.

3. 55 weaver respondents out of 70 belong to backward community with $78.57 \%$,

4. Majority of the women respondents $(81.43 \%)$ belong to Hindu religion

5. Majority of the women respondents 61 out of $70(87.14 \%)$ are married

6 It is observed that $30 \%$ of women respondents are illiterates.

7. Majority of the respondents (64.29\%) are under nuclear families and $35.71 \%$ are under joint families.

8. $50 \%$ of the women weaver respondents have medium size of family which consists of 4 to 6 members.

9. Majority of the respondents $(85.71 \%$ ) have own houses and $14.29 \%$ of the respondents are living in rented houses.

10. Majority of the respondents $(55.71 \%)$ are dwelling in thatched houses. A few respondents $(10.0 \%)$ are dwelling in R.C.C houses.

11. Majority of the women weaver respondents $(74.29 \%)$ are choosing the occupation by inheritance

12. Majority of the respondents $(54.29 \%)$ are working under co-operative societies.. Only $5.71 \%$ of the respondents are independent weavers.

13. Majority of the respondents (90\%) are working up to 8 hours per day and only $10 \%$ of the weavers are working 8-12 hours per day.

14. Majority of the respondents $(57.14 \%)$ are earning in between Rs. 100 to 200 per day. Only $5.71 \%$ of the respondents income is Rs.300 above.

15. Majority of the respondents $(42.86 \%)$ are suffering form backpain followed by $32.86 \%$ respondents suffering from eye sight /cataract. $18.57 \%$ of the respondents are suffering from joint pains and knee pains and only $5.71 \%$ of the respondents suffering from the problem of lungs.

Summary \& Conclusion

The central and state government should take some steps at different levels. To overcome the problems of women weavers, easy credit and cheep credit should be provided to women weavers through the banks, other financial institutions and government. Handloom weaving plays an active role in the growth process of the state as well as the nation. This sector has been considered prominent because of the traditional artisan craft skills of the weavers which meet the local needs and demands. Handloom sector has different strengths in the modern economy. It is simple, and is associated with appropriate technology. The world, which is seeking for clean air and water, handlooms are well suited because they are eco-friendly in nature. Handloom sector has self sustaining mechanism, training for irrespective of gender. The inheritance of skills and capacities is beyond the realm and reach of any modern training and educational institution. There is a sufficient flexibility for all types of communities to take up handloom weaving as a profession.

References

Srinivasachari P.(1965), The Handloom Industry, Khadi and Village Industries Commission Publication, pp.1-12. The Handloom and Women, Khadi Gramodyog, Vol.7,No.2,pp.76-78. Hussain M.I., (1975),

Parikh, Indira,(1991), "Women Weavers”, Oxford and IBH Publishing Pvt. Ltd. New Delhi, Bombay and Calcutta. Narashimhan, Sakuntala (1999) : "Empowerment of Women : An Alternative Strategy for Rural India," Saga Publication India Pvt. Ltd, New Delhi. 
Reddy, Narasimha, (2006), Women Handloom Weavers, Facing the burnt, Gender and Trade Policy, Centre for Handloom Information and Policy, pp. 1-7.

Ashalata P, Acharya.M.,(2009) "Changing Families and Life Style of Women weavers From Co-Operative Society at Manipur",Shodh. Samiskshaa Mulyankan( International Research Journal)- ISSN - 0974-2832 Vol.II, Issue-7.

Female Work Participation Rates in India, An Analysis, Rao D.P.(Eds)Status of Women in Education, Employment and Social Exclusion, Serials Publications, New Delhi,pp.141-159. (2011)

Women in Handloom Industry: Problems and Prospects, B. Premsundar \& J.Kannan, Journal of Economic and Business Review, December 2013 www.epratrust.com Vol - 1 Issue- 1 p.32-38.

Women in Handloom Industry: Problems and Prospects, B. Premsundar \& J.Kannan, Journal of Economic and Business Review, December 2013 www.epratrust.com Vol - 1 Issue- 1 p.32-38

Tasneem Shazli, and prof. Abdul Munir, Female work participation in Handloom industry- A case study of Mubarakpur town, Azangarh District, U.P. Journal of education and society policy. 1: (2014).

\section{Copyrights}

Copyright for this article is retained by the author(s), with first publication rights granted to the journal. This is an open-access article distributed under the terms and conditions of the Creative Commons Attribution license (http://creativecommons.org/licenses/by/4.0/) 